Kumawula, Vol. 2, No.3, Desember 2019, Hal 226 - 235 DOI:http://10.24198/kumawula.v1i3.24561

ISSN 2620-844X (online)

Tersedia online di http://jurnal.unpad.ac.id/kumawula/index

\title{
SOSIALISASI PENGELOLAAN SAMPAH DI DESA SUKARAPIH SEBAGAI UPAYA PREVENTIF PENCEMARAN SUNGAI CITARUM
}

\author{
Muchtaridi $^{1 *}$, Cecep Suhandi ${ }^{2}$, Abednego K. Gwiharto ${ }^{3}$ \\ Fakultas Farmasi Universitas Padjadjaran ${ }^{1}$ \\ *Korespondensi: muchtaridi@unpad.ac.id
}

\begin{abstract}
ABSTRAK
Sungai Citarum merupakan sungai terpanjang di Indonesia. Sebagai sumber air yang digunakan oleh masyarakat, sungai Citarum belum memenuhi standar kelayakan yang diharapkan. Salah satu masalah yang menyebabkan hal ini adalah pencemaran sungai oleh sampah. Salah satu daerah aliran sungai (DAS) yang merupakan hulu dari sungai Citarum terletak di Desa Sukarapih. Dengan demikian, melalui program "Kuliah Kerja Nyata Citarum Harum (KKN) Desa Sukarapih" diharapkan dapat meningkatkan kualitas sanitasi dan kebersihan sungai Citarum. Berbagai program kegiatan telah dilakukan, salah satunya adalah sosialisasi pengelolaan sampah Sungai Citarum ke berbagai lapisan masyarakat di Desa Sukarapih. Kegiatan selanjutnya adalah menyelenggarakan lokakarya (Workshop) pengelolaan sampah untuk siswa Sekolah Dasar Magarluyu, Desa Sukarapih, Kecamatan Sukasari, Kabupaten Sumedang. Diperoleh korelasi yang signifikan $(\mathrm{P}=0,018)$ dari hasil pengajuan lokakarya kepada siswa Sekolah Dasar mengenai kesadaran diri dalam menjaga kebersihan sungai. Sementara korelasi yang tidak signifikan diperoleh $(\mathrm{P}=0,253)$ dari hasil penyampaian seminar ke berbagai lapisan masyarakat desa.
\end{abstract}

Kata Kunci: Sungai Citarum, Desa Sukarapih, Sampah

\section{SOCIALIZATION REGARDING WASTE MANAGEMENT IN SUKARAPIH VILLAGE AS PREVENTATIVE EFFORTS TOWARDS THE POLUTION OF CITARUM RIVER}

\begin{abstract}
Citarum River is the longest river in Indonesia. As a source of water used by many communities, Citarum River has not met the proper eligibility standards. One problem that causes this is the pollution of the river through garbage. One of the river basins (DAS) which is the upstream of the Citarum river is located in Sukarapih Village. Thus, through the program "Citarum Harum Social Service (KKN) Sukarapih Village" is expected to improve the quality of sanitation and cleanliness of the Citarum river. Various program activities have been carried out, one of which is the socialization of Citarum River waste management to various levels of society in Sukarapih Village. The next activity was to organize a waste management workshop for Magarluyu Elementary School students, Sukarapih Village, Sukasari District, Sumedang Regency. A significant correlation was obtained $(P=0,018)$ from the results of the workshop submission to elementary students regarding self-care in maintaining river cleanliness. While an insignificant correlation was obtained $(P=0,253)$ from the results of the seminar delivery to various layers of village community.
\end{abstract}

Keywords: Citarum River, Sukarapih Village, Waste 


\section{PENDAHULUAN}

Sungai Citarum sebagai salah satu sumber aliran air sering kali mengalami permasalahan yang diakibatkan oleh pengolahan sampah yang kurang baik. Sungai citarum merupakan sungai yang terbentang dengan luas $5.960 \mathrm{~km}^{2}$ di Provinsi Jawa Barat, bersumber dari Gunung Wayang hingga ke bagian utara dari pulau Jawa dekat dengan Jakarta (Bukit, 1995). Penumpukan sampah di Daerah Aliran Sungai (DAS) menimbulkan berbagai masalah, seperti banjir, kerusakan ekosistem, dan sanitasi air yang buruk.

Menurut Undang-Undang Republik Indonesia Nomor 18 Tahun 2008 Tentang Pengelolaan Sampah, sampah merupakan material sisa yang dihasilkan dari suatu kegiatan, baik konsumsi maupun produksi manusia ataupun proses alami (Kasih et al., 2018). Peningkatan aktivitas produksi maupun konsumsi masyarakat berbanding lurus dengan jumlah sampah yang dihasilkan. Kurangnya kesadaran masyarakat dalam pentingnya mengelola sampah dengan baik dapat menimbulkan permasalahan serius terhadap lingkungan. Salah satu dampak negatif yang dapat ditimbulkan dari pengelolaan sampah yang kurang baik adalah akumulasi sampah pada daerah aliran sungai (DAS) (Hasibuan, 2016). Pengetahuan, sikap, serta keterampilan warga dalam mengelola sampah rumah tangga menjadi salah satu hal penting dalam pengelolaan sampah (Akhtar dan Soetjipto, 2014). Pendidikan mengenai kepedulian lingkungan sejak dini dapat menentukan karakter serta kebiasaan di masa yang akan datang yang dapat berpengaruh terhadap kondisi lingkungan sekitar (Chun, et al., 2012).

Penanganan terkini dari pengeolaan sampah yang populer selama ini adalah dengan prinsip 3R (Reuse, Reduce, Recycle) (Surono dan ismanto, 2016). Selain itu, pengelolaan sampah berbasis koperasi seperti bank sampah juga banyak dimintai oleh berbagai lapisan masyarakat (Asteria dan Heru, 2016). Pengembangan bank sampah berbasis komunitas secara bijak dapat mengurangi sampah dan mudah dalam pengangkutan ke Tempat Pembuangan Akhir (TPA) (Purba, et al., 2014). Akan tetapi, seluruh program yang dicanangkan perlu disosialisasikan dengan baik kepada target masyarakat. Dengan demikian, seluruh program baik yang telah direncanakan dapat diimplementasikan secara baik dan berkesinambungan.

Desa Sukarapih merupakan suatu daerah yang memiliki wilayah yang cukup strategis. Desa Sukarapih terletak di wilayah kecamatan Sukasari, Kabupaten Sumedang dan berbatasan langsung dengan kecamatan Tanjungsari di bagian selatan . Berdasarkan data yang diperoleh pada tahun 2013, Desa Sukarapih memiliki luas wilayah \pm 141 hektar. Secara administratif, Desa Sukarapih terdiri dari 10 Rukun Warga (RW) dan 33 Rukun Tetangga (RT) (Imanuddin, 2017).

\section{METODE}

Penelitian ini menggunakan pendekatan kuantitatif, dengan teknik penelitian survei. Penelitian dilaksanakan pada bulan Oktober-November 2019. Data primer diperoleh dari berbagai golongan 
masyarakat dan siswa SD yang mengikuti Sosialisasi melalui wawancara langsung dengan menggunakan kuisioner sebagai alat bantu yang telah dipersiapkan sebelumnya. Adapun kegiatan sosialisasi yang dilaksanakan terbagi menjadi dua jenis, yakni seminar terhadap masyarakat dewasa dan workshop terhadap siswa SD. Masyarakat dewasa yang ikut serta sebagai subjek penelitian terdiri dari seluruh ketua Rukun Warga (RW), kepala desa, kelompok PKK, dan perangkat desa lainnya. Sedangkan siswa SD yang ikut serta sebagai subjek penelitian merupakan siswa SD Margaluyu Desa Sukarapih, Sumedang. Adapun data sekunder diperoleh dari hasil survey langsung terhadap beberapa kelompok keluarga (KK) Desa Sukarapih melalui metode Random Sampling serta data kependudukan Desa Sukarapih.

Pada tahap prapelaksanaan kegiatan terdiri dari:

1. Survey tingkat Desa dan Kecamatan

2. Penentuan tempat Sosialisasi Pengelolaan Sampah

3. Mempersiapkan alat-alat bantu Sosialisasi Pengelolaan Sampah

Tahap pelaksanaan dilakukan hal-hal beikut:

1. Kuesioner tentang kesadaran menjaga lingkungan sekitar dari cemaran sampah

2. Sosialisasi Pengelolaan Sampah

3. Pre tes dan post tes

\section{HASIL DAN PEMBAHASAN}

\section{A. Aspek Demografis}

Desa Sukarapih memiliki 2.217 KK dengan total penduduk 7.187 orang, diantaranya 3.678 orang berjenis kelamin laki-laki dan 3509 orang berjenis kelamin perempuan. Penduduk Desa Sukarapih memiliki rentang usia yang bervariasi yaitu dari 0 sampai 65 tahun ke atas, rincian usia penduduk dapat dilihat pada Tabel 1. Pendidikan penduduk Desa Sukarapih dimulai dari TK/play group hingga jenjang S-3, rincian pendidikan penduduk disajikan pada Tabel2.

Tabel 1. Usia Penduduk Desa Sukarapih

\begin{tabular}{|c|c|c|}
\hline \multirow{2}{*}{ Usia (Tahun) } & \multicolumn{2}{|c|}{ Jumlah (orang) } \\
\cline { 2 - 3 } & Laki-laki & Perempuan \\
\hline $0-4$ & 123 & 122 \\
\hline $5-6$ & 103 & 115 \\
\hline $7-12$ & 489 & 355 \\
\hline $13-15$ & 158 & 239 \\
\hline $16-18$ & 256 & 169 \\
\hline $19-25$ & 506 & 412 \\
\hline $26-64$ & \multicolumn{2}{|c|}{3.679} \\
\hline 65 keatas & \multicolumn{2}{|c|}{451} \\
\hline Total & \multicolumn{2}{|c|}{7.186} \\
\hline
\end{tabular}


Tabel 2. Pendidikan Penduduk Desa Sukarapih

\begin{tabular}{|l|r|}
\hline \multicolumn{1}{|c|}{ Tingkat pendidikan } & Jumlah (orang) \\
\hline Usia 3 -6 tahun belum masuk TK & 1.155 \\
\hline Usia 3 -6 tahun sedang TK/play group & 752 \\
\hline Tamat SD/Sederajat & 1.579 \\
\hline SMP/Sederajat & 1.286 \\
\hline SMA/Sederajat & 1.761 \\
\hline Tamat D2/Sederajat & 56 \\
\hline Tamat D3/Sederajat & 185 \\
\hline Tamat S1/Sederajat & 367 \\
\hline Tamat S2/Sederajat & 40 \\
\hline Tamat S3/Sederajat & 4 \\
\hline Total & 7.186 \\
\hline
\end{tabular}

Mata pencaharian pokok penduduk Desa Sukarapih juga bervariasi, informasi lebih lengkapnya dapat dilihat pada Tabel 3. Agama atau aliran kepercayaan penduduk Desa Sukarapih disajikan pada Tabel 4. Informasi kewarganegaraan penduduk Desa Sukarapih disajikan pada Tabel 5.

Tabel 3. Mata Pencaharian Pokok Penduduk Desa Sukarapih

\begin{tabular}{|l|c|}
\hline \multicolumn{1}{|c|}{ Mata Pencaharian } & Jumlah (orang) \\
\hline Petani & 96 \\
\hline Buruh tani & 189 \\
\hline Pegawai swasta & 654 \\
\hline Wiraswasta & 1.185 \\
\hline Pegawai Negeri Sipil & 199 \\
\hline Mengurus rumah tangga & 1.659 \\
\hline Pelajar & 1.572 \\
\hline Tidak bekerja & 1.401 \\
\hline TNI/POLRI & 18 \\
\hline Pensiunan & 76 \\
\hline Total & 7.186 \\
\hline
\end{tabular}

Tabel 4. Agama/Aliran Kepercayaan Penduduk Desa Sukarapih

\begin{tabular}{|c|c|}
\hline Agama & Jumlah (orang) \\
\hline Islam & 7.132 \\
\hline Kristen & 48 \\
\hline Katolik & 1 \\
\hline Hindu & 1 \\
\hline Khonghucu & 3 \\
\hline Jumlah & 7.186 \\
\hline
\end{tabular}


Tabel 5. Kewarganegaraan Penduduk Desa Sukarapih

\begin{tabular}{|c|c|c|}
\hline \multirow{2}{*}{ Kewarganegaraan } & \multicolumn{2}{|c|}{ Jumlah (orang) } \\
\cline { 2 - 3 } & Laki-laki & Perempuan \\
\hline Warga Negara Indonesia & 3.678 & 3.509 \\
\hline Warga Negara Asing & 1 & \\
\hline Total & \multicolumn{2}{|c|}{7.187} \\
\hline
\end{tabular}

\section{B. Aspek Pengetahuan}

Sampah merupakan salah satu permasalahan krusial yang ada pada Sungai Citarum. Sebagai salah satu desa yang dialiri oleh Hulu Sungai Citarum, maka pengetahuan mengenai sampah dan Sungai Citarum itu sendiri merupakan hal yang penting untuk diketahui. Oleh karena itu, telah dilakukan survei dengan cara pemberian kuesioner kepada 20 orang responden yang merupakan pemuka Desa Sukarapih. Survei ini dilakukan sebagai wujud sosialisasi terhadap warga sekaligus memberikan solusi-solusi praktis pengelolaan sampah.

Untuk mengetahui tingkat pengetahuan dasar masyarakat Desa Sukarapih mengenai sampah dan Sungai Citarum, kami menyusun dan menyebarkan kuesioner berisikan beberapa pertanyaan yang mewakili indikator pengetahuan mengenai sampah dan Sungai Citarum. Indikator penilaian aspek pengetahuan disajikan pada Tabel 6 .

Tabel 6. Indikator Penilaian Aspek Pengetahuan

\begin{tabular}{|c|l|c|c|c|}
\hline \multirow{2}{*}{ No. Indikator } & \multicolumn{3}{c|}{ Skor } \\
\cline { 3 - 5 } & & Benar & Salah & \% benar \\
\hline 1 & Pengetahuan mengenai Sungai Citarum & 15 & 0 & 100 \\
\hline 2 & Pengetahuan mengenai sampah & 5 & 0 & 100 \\
\hline 3 & Pengetahuan mengenai jenis-jenis sampah & 10 & 5 & 67 \\
\hline 4 & Pengetahuan mengenai pengelolaan sampah & 20 & 5 & 80 \\
\hline \multicolumn{2}{r|}{ Total } & 50 & 10 & 83 \\
\hline
\end{tabular}

Tabel 7. Data Aspek Pengetahuan Sampah

\begin{tabular}{|c|c|c|c|c|}
\hline \multirow{2}{*}{ Pertanyaan } & \multicolumn{2}{|c|}{ Jawaban } & \multirow{2}{*}{ Total } & \multirow{2}{*}{ Persentase } \\
\cline { 2 - 4 } & Benar & Salah & & \\
\hline 1 & 20 & 0 & 20 & $100 \%$ \\
\hline 2 & 20 & 0 & 20 & $100 \%$ \\
\hline 3 & 16 & 4 & 16 & $80 \%$ \\
\hline 4 & 19 & 1 & 19 & $95 \%$ \\
\hline 5 & 13 & 7 & 13 & $65 \%$ \\
\hline 6 & 20 & 0 & 20 & $100 \%$ \\
\hline 7 & 20 & 0 & 20 & $100 \%$ \\
\hline
\end{tabular}




\begin{tabular}{|c|c|c|c|c|}
\hline 8 & 19 & 1 & 19 & $95 \%$ \\
\hline 9 & 17 & 3 & 17 & $85 \%$ \\
\hline 10 & 20 & 0 & 20 & $100 \%$ \\
\hline 11 & 30 & 0 & 20 & $100 \%$ \\
\hline 12 & 30 & 1 & 19 & $95 \%$ \\
\hline \multicolumn{5}{|c|}{ Rata-rata } \\
\hline
\end{tabular}

Berdasarkan data aspek pengetahuan sampah pada Tabel 7, didapatkan bahwa rata-rata pemahaman warga mengenai sampah sudah baik. Rata-rata yang didapatkan sebesar $92 \%$.

\section{Aspek Kesadaran}

Setelah menganalisis aspek pengetahuan mengenai sampah dan Sungai Citarum, perlu dilakukan analisis serupa pada aspek perilaku masyarakat terhadap pembuangan dan pengelolaan sampah. Adapun indikator penilaian aspek perilaku dapat dilihat pada Tabel 8.

Tabel 8. Indikator Penilaian Aspek Perilaku

\begin{tabular}{|c|l|c|c|}
\hline \multirow{2}{*}{ No. } & \multirow{2}{*}{ Indikator } & \multicolumn{2}{|c|}{ Skor } \\
\cline { 3 - 4 } & & Ya & Tidak \\
\hline 1 & Perilaku membuang sampah & 20 & 0 \\
\hline 2 & Perilaku dalam pengelolaan sampah & 20 & 0 \\
\hline \multicolumn{2}{|c|}{ Total } & 40 & 0 \\
\hline
\end{tabular}

Tabel 9. Data Aspek Perilaku

\begin{tabular}{|c|c|c|c|c|}
\hline \multirow{2}{*}{ Pertanyaan } & \multicolumn{2}{|c|}{ Jawaban } & \multirow{2}{*}{ Total } & \multirow{2}{*}{ Persentase } \\
\cline { 2 - 4 } & Ya & Tidak & & \\
\hline 1 & 18 & 3 & 17 & $85 \%$ \\
\hline 2 & 19 & 2 & 18 & $90 \%$ \\
\hline 3 & 22 & 0 & 20 & $100 \%$ \\
\hline 4 & 23 & 0 & 20 & $100 \%$ \\
\hline 5 & 24 & 0 & 20 & $100 \%$ \\
\hline 6 & 23 & 2 & 18 & $90 \%$ \\
\hline 7 & 24 & 2 & 18 & $90 \%$ \\
\hline 8 & 15 & 13 & 7 & $35 \%$ \\
\hline \multicolumn{3}{|c|}{ Rata-rata } & $86 \%$ \\
\hline
\end{tabular}

Berdasarkan analisis data aspek perilaku, rata-rata masyarakat sudah cukup baik dalam membuang dan mengelola sampah. Rata-rata yang didapatkan adalah sebesar $86 \%$.

\section{PRE TEST \& POST TEST}

Selain analisis kuesioner, penlilaian terhadap pre test dan post test juga dilakukan untuk 
mengetahui korelasi dan pengaruh sosialisasi mengenai sampah terhadap pemahaman masyarakat. Hasil penilaian pre test dan post test dapat dilihat pada Tabel 8.10 . Grafik nilai pre test dan post test disajikan pada Gambar 8.1.

Tabel 10. Nilai Pre Test dan Post Test

\begin{tabular}{|c|c|c|c|}
\hline No. & Nama & Pre Test & Post Test \\
\hline 1. & Nikarna & 80 & 95 \\
\hline 2. & Mustofa & 90 & 100 \\
\hline 3. & Setiawan & 95 & 95 \\
\hline 4. & Toto & 80 & 85 \\
\hline 5. & Azis & 100 & 100 \\
\hline 6. & Holis & 95 & 90 \\
\hline 7. & Deedee & 95 & 95 \\
\hline 8. & Iyan & 95 & 95 \\
\hline 9. & Muhtar & 80 & 90 \\
\hline 10. & Oding & 70 & 95 \\
\hline 11. & Sepul & 95 & 85 \\
\hline 12. & Iis & 90 & 90 \\
\hline 13. & Anang & 90 & 90 \\
\hline 14. & Nunung & 95 & 95 \\
\hline 15. & Nella & 95 & 95 \\
\hline 16. & Gunawan & 85 & 95 \\
\hline 17. & Eti & 85 & 95 \\
\hline 18. & Erni & 90 & 95 \\
\hline 19. & Surya & 80 & 90 \\
\hline 20. & Achdi & 95 & 100 \\
\hline \multicolumn{2}{|c|}{ Rata-rata } & 89 & 93,5 \\
\hline
\end{tabular}

Adapun hasil dari workshop pengelolaan sampah terhadap siswa SD Margaluyu Desa Sukarapih tertera [ada tabel berikut:

Tabel 11. Hasil Pre Test dan Post Test

\begin{tabular}{|c|l|r|r|}
\hline No. & \multicolumn{1}{|c|}{ Nama } & Pre Test & Post Test \\
\hline 1. & Nabilla & 40 & 100 \\
\hline 2. & Naswa & 40 & 100 \\
\hline 3. & Hapsah & 80 & 100 \\
\hline 4. & Aji & 60 & 100 \\
\hline 5. & Shahrul & 60 & 100 \\
\hline 6. & Elsa & 100 & 100 \\
\hline 7. & Aini & 100 & 100 \\
\hline 8. & Riani & 100 & 100 \\
\hline 9. & Mawaj & 60 & 100 \\
\hline 10. & M. Syahrul & 20 & 100 \\
\hline 11. & Dimas & 80 & 100 \\
\hline
\end{tabular}




\begin{tabular}{|c|l|r|r|}
\hline 12. & Della & 60 & 80 \\
\hline 13. & Raini & 60 & 100 \\
\hline 14. & Qomala & 40 & 100 \\
\hline 15. & Dea & 60 & 100 \\
\hline 16. & Rafeyra & 40 & 100 \\
\hline 17. & Siska & 0 & 100 \\
\hline 18. & Rendi & 40 & 100 \\
\hline 19. & Ahmad & 40 & 100 \\
\hline 20. & Chika & 80 & 100 \\
\hline \multicolumn{2}{|c|}{ Rata-rata } & 58 & 99 \\
\hline
\end{tabular}

Nilai pre test dan post test kemudian diuji menggunakan uji Korelasi dan Paired T Test untuk mengetahui korelasi keduanya serta pengaruh Sosialisasi (seminar dan workshop) terhadap pre test dan post test.

Tabel 12. Hasil Uji Korelasi Pre Test dan Post Test Program Seminar

\begin{tabular}{|c|c|c|c|c|}
\hline \multicolumn{2}{|c|}{} & N & Correlation & Sig. \\
\hline Pair 1 & Seminar & 20 & .268 & .253 \\
\hline
\end{tabular}

Berdasarkan hasil uji Korelasi, nilai Pearson Correlation yang didapatkan adalah 0,268 yang menunjukkan bahwa nilai pre test dan nilai post test berkorelasi lemah. Nilai pre test dan post test juga tidak menunjukkan korelasi secara nyata dilihat dari nilai Sig. $>0,05$ yaitu sebesar 0,253.

Adapun hasil uji korelasi antara Pre-Test dan Post-Test Program Workshop tertera pada tabel berikut:

Tabel 13. Hasil Paired T Test Nilai Pre Test dan Post Test Program Workshop

\begin{tabular}{|c|c|c|c|c|c|}
\hline \multicolumn{2}{|c|}{} & Upper & $\mathrm{t}$ & $\mathrm{df}$ & $\begin{array}{c}\text { Sig. (2- } \\
\text { tailed }\end{array}$ \\
\hline Pair 1 & Workshop & -.86683 & -2.592 & 19 & .018 \\
\hline
\end{tabular}

Dari luaran Paired T Test, didapatkan hasil bahwa sosialisasi dengan Workshop yang dilakukan memberikan pengaruh terhadap nilai pre test dan post test. Hal ini dibuktikan dengan nilai Sig. $<0,05$ yaitu sebesar 0,018 .

\section{SIMPULAN}

Masyarakat Desa Sukarapih ini masih dikatakan kurang sadar mengenai pentingnya menjaga kebersihan sungai dari cemaran sampah. Oleh karena itu, mahasiswa memberikan sosialisasi dalam bentuk seminar dan workshop sebagai upaya preventif penanggulangan pencemaran sungai Citarum. Setelah melaksanakan pengujian pre-test dan post-test dengan alat kuisioner terhadap pengaruh dari penyampaian sosialisasi pengelolaan sampah, diperoleh korelasi yang signifikan dari program 
sosialisasi dengan bentuk workshop. Berbeda halnya dengan program sosisalisai berbentuk seminar, diperoleh korelasi yang tidak signifikan antara uji pre-test dan post-test. Merujuk pada perbandingan antara pre test dan post test tersebut, maka dapat disimpulkan bahwa sosialisasi dalam bentuk workshop dapat memberikan pengaruh atau dampak terhadap masyarakat dalam memahami pengelolaan sampah. Sehingga sebaiknya sosialisasi diberikan secara berulang agar dapat menambah pemahaman tentang pentingnya menjaga kebersihan sungai dan pengelolaan sampah.

\section{UCAPAN TERIMA KASIH}

Terima kasih kami harutkan kepada Kemristekdikti yang telah mendanai KKN Tematik Citarum Harum ini. Kami juga mengucapkan terima kasih kepada Tim KKN Mahasiswa Desa Sukarapih atas Nama Naufal Muhammad R dan kawan-kawan.

\section{DAFTAR PUSTAKA}

Akhtar, H., dan Soetjipto, H. P. 2014. Peran Sikap dalam Memediasi Pengaruh Pengetahuan Terhadap Perilaku Minimisasi Sampah Pada Masyarakat Terban, Yogyakarta. Jurnal Manusia dan Lingkungan, 21(3):386-392.

Asteria, D., dan Heru, H. 2016. Bank Sampah Sebagai Alternatif Strategi Pengelolaan Sampah Berbasis Masyarakat Di Tasikmalaya. J. Manusia Dan Lingkungan, 23(1): 136-141

Bukit, N. T. 1995. Water Quality Conservation for the Citarum River in West Java. Water Science and Technology 31(9): 1-10.

Chun, M. H., Sulaiman, W. N. A., dan Samah, M. A. A. 2012. A Case Study on Public Participation for the Conservation of a Tropical Urban River. Pol. J. Environmental Study, 2(4): 821-829.

Hasibuan, R. 2016. Analisis Dampak Limbah/Sampah Rumah Tangga Terhadap Pencemaran Lingkungan Hidup. Jurnal Ilmiah “Advokasi”, 4(1): 42-52.

Imanuddin, A. M. 2017. Desa Sukarapih. Diakses secara online di http://sumedangtandang.com/direktori/detail/desa-sukarapih.htm [Diakses pada 7 November 2019].

Kasih, D., Ivan, I., Lies, S., Munir, T., Isra', S. 2018. Studi Perancangan Dan Pemanfaatan TPS 3R Untuk Sampah TPS (Tempat Pengolahan Sampah Rumah Tangga). Jurnal Dampak, 15(1): $16-22$.

Purba, H.D., Meidiana, C., dan Adrianto, D.W., 2014. Waste Management Scenario through Community Based Waste Bank: A Case Study of Kepanjen District, Malang Regency, Indonesia. International Journal of Environmental Science and Development, 5(2):212-216. 
Republik Indonesia. 2008. Undang-Undang Republik Indonesia Nomor 18 Tahun 2008 Tentang Pengelolaan Sampah.

Surono, U. B., dan Ismanto. 2016. Pengolahan Sampah Plastik Jenis PP, PET dan PE Menjadi Bahan Bakar Minyak dan Karakteristiknya. Jurnal Mekanika dan Sistem Termal, 1(1): 32-37. 